\title{
OBSESSIONS OF INFANTICIDE AND IMMINENT PSYCHOSIS
}

\author{
A. H. CHAPMAN*, MIRIAM CHAPMAN-SANTANA*, SIMONE A. TEIXEIRA*
}

\begin{abstract}
In young mothers an obsession of infanticide, that is, fear that they may murder their children, may be coupled with an obsession of imminent psychosis, that is, fear that the first obsession is a sign of approaching insanity. Sixteen mothers with this clinical picture were evaluated in interviews. Seven of them entered psychotherapy and improved. The causative factors in childhood and adolescence wich led to the later development of these obsessive difficulties are analyzed. Even when psychotherapy was not possible, as was the case in nine patients, they should be strongly reassured and explanations should be given about the nature of the problem, for such encouragement and clarification helps them to improve to a significant extent. The prognosis of patients who have systematic psychoterapy is good.
\end{abstract}

KEY WORDS: obsession, infanticide, psychotherapy.

\section{Obsessōes de infanticídio e psicose iminente}

RESUMO - Em mães jovens, uma obsessão de infanticídio, ou seja, medo de que possam vir a matar seus próprios filhos pode estar associada a uma outra obsessāo, de uma psicose iminente, isto é medo de que a primeira obsessão esteja sinalizando um perigo iminente de psicose. Dezesseis mães com este quadro foram avaliadas por meio de entrevistas clínicas. Sete puderam submeter-se a psicoterapia e melhoraram bastante. São analisados os fatores interativos que, na infância e adolescência, concorrem para o desencadeamneto desses comportamentos obsessivos; mesmo quando nāo seja possivel a situaçāo ideal de uma psicoterapia mais extensa, como ocorreu com nove pacientes, elas devem ser tranquilizadas e animadas por meio de explicaçōes quanto à natureza do problema, pois só com este encorajamento elas podem apresentar melhoras apreciáveis. O prognóstico das pacientes que se submetem a terapia mais extensa é favorável.

PALAVRAS-CHAVE: obsessão, infanticídio, psicoterapia.

A special type of obsession in women is the persistent fear that they will kill their children. This is usually accompanied by a fear of suddenly becoming insane. These two obsessions reinforce each other. These mothers fear that the thought of killing their children indicates psychosis, and that a consenquence of abruptly ocurring psychosis will be the murder of them ${ }^{2}$.

It should be emphasized that these patients do not have urges to kill their children; they have instead an ever present dread, that they may do so ${ }^{7}$. None of the patients reported here had a history of violent acts against persons, animals or things; they had never attacked people, or abused pets or broken household objects. In addition, none of them had ever directed violence against themselves in suicidal threats, gestures or attempts. They were, on the contrary, passive women who rarely resorted to even mild verbal expressions of anger or resentment. Deciding whether a woman has urges to kill her children or obsessive fears that she will do so is usually not a difficult decision for the clinician when both the patient and a near relative are carefully interviewed.

*From the Samur Hospital and the Universidade Estadual do Sudoeste da Bahia, Vitória da Conquista, Bahia, Brazil. Aceite: 27-novembro-1195. 


\section{CLINICAL CHARACTERISTICS AND METHODS}

In the past fifteen years we have sixteen young mothers with coupled obsessions of infanticide and imminent psychosis. The youngest of them was nineteen years old and the oldest was thirty-two; the average age was twenty-five. Eight of these patients had two children, seven of them had three children, and one had four children. The children ranged in age from two months to ten years and they were about evenly divided in sex.

The length of time between the onset of the obsessions and medical consultation about them varied from a few weeks to one and a half years. These patients characteristically dreaded that disclosure of their fears to a physician would result in immediate long-term confinement in a psychiatric hospital. In some cases the woman feared that her husband and others would at once take her away from her children and send her to stay with watchful relatives in a distant city. In ten cases the initial medical consultation was with a general phsysician in the patient's home community, and in six others the first medical contact was with ourselves. The general physicians who were consulted as a rule used strong reassurances and mild antianxiety medication to assuage the disorder; in other instances the general physician promptly recommended psychiatric evaluation with one of the authors.

Nine of the patients were only seen diagnostically; for various reasons they declined to enter psychoterapy. In most cases the long distances they had to travel for psychiatric consultations would have made treatment difficult; they had to travel up to three hundred kilometers to see us and psychiatric help was unavailable at places nearer to their homes. In other cases the patients felt that talking about their conditions in any more than a diagnostic manner would be impossible for them. In these cases massive, emphatic reassurances to the patient and her accompanying relative, who was usually her husband, formed the limit of what we could do. We explained that there were logical causes for such fears in the present and past life experiences of a patient, and that these persistent thoughts were not strange, inexplicable things that suddenly erupted in people. We reassured both the patient and her companion that the chances that she would become violent or psychotic were no greater than in general population ${ }^{2}$ and that the basic problems of such women usually were undue passivity and the bottling up of feelings rather than their violent expression. As a side note it should be mentioned that in almost all cases the patient's husband or other close relative was not worried that the patient might become violent.

None of these sixteen patients was hospitalized. To have done so, even for the purpose of a brief period of daily intensive psychotherapy, would have suggested to the patient that despite our reassurances to the contrary we considered her potentially dangerous to her children and that temporary separation from them was advisable. We did not prescribe medication for any of these patients. We explained that antianxiety medication would help the patient little and would deter her from thinking about her past and current life experience as the sources of her fears ${ }^{2}$. A patient who takes medication for this kind of problem often adopts a "wait and see" attitude and feels that the problem is merely "to find the right medication for my trobule". In no case did a depressive thread in the patient's condition satisfy the criteria which suggest that antidepressant medication might be helpful.

Most of these patients had horror-filled daydreams of standing over the mutilated bodies of their children on blood stained floors. They fantasied gruesome reports of themselves on television newcasts in which, disheveled and handcuffed, they were being led away from their homes while their distraught husbands and neighbors dumbly watched. Such terror-filled speculations were accompanied by much anxiety. In all but two cases the patient told her husband of her obsessive fears within a few days after they began, and told no one else. They tended to be more comfortable if another person,. who might be merely and early adolescent, were constantly in the home. The patient felt that such a person would restrain her if she suddenly became psychotic and violent, and would summon others to help. In five cases the patient could specify a particular event which precipitated her symptoms. The obsessive disorders of three of them began two or three months after the birth of a child, and one patient's obsessions began after seeing in a television newscast an account of a woman who had murdered her child. Another patient stated that her difficulty started shortly after her mother's death.

Their obsessive fears tended to fluctuate in intensity, with "good days" and "bad days", and "good mornings" and "bad mornings". The first hour or two of each day often were the most difficult ones for them; they worried that "this is the day it will happen". Bedtime was another stressful period since they feared that the loss of self-vigilance and self-control that drowsiness involves would unleash their murderous assaults. Insomnia was complaint in almost all these patients.

None of these patients was psychotic or became so, though all of them had a certain amount of depressiveness; this seemed realistic to them in view of the catastrophe that they felt each day might bring?. Some of them after the onset of their obsessions began to have headaches, lack of appetite, fatigue, upper abdominal pain and pain in the thoracic, lumbar and posterior neck muscle groups. None of them had had other kinds of obsessions in the past, and neither at this time nor previoulsy had they had compulsive symptoms or 
rituals. They did not have phobias; some of them, however, avoided driving automobiles after the onset of their obsessions for fear they might swerve onto sidewalks and kill people, particularly children, or deliberately run down pedestrians or cyclists.

Toward the end of the initial diagnostic session the interviewer emphasized the commonness of this kind of problem and stressed that logical causes for it usually could be found in both the early and recent life experiences of the patient. Each patient found it reassuring to learn that other women had suffered from similar difficulties; she had hitherto felt that she was undergoing a strange, inexplicable experience that was unique to herself. The therapist also stressed that he was aware that reassurence alone would not solve the problem; it would only take the edge off the patient's anxiety. The rest of the turmoil, however, could be resolved by exploring the roots of it; in this process she could develop new awareness of her feelings and evolve new ways of handling them.

\section{PSYCHOTHERAPY OF THESE PATIENTS}

Seven of these patientis entered psychotherapy and were seen in fifty-minute sessions in a face to face setting once weekly over periods that ranged from five to fourteen months ${ }^{4}$. Psychotherapy began by examining the patient's current emotional functioning and interpersonal relationships. Many aspects of her interpersonal life were investigated. They included her capacities for giving and receiving affection, for entering into competition with others, for making compromises, for being firm and assertive when circumstances required such attitudes, for getting angry once in a while, and for general emotional give-and-take with people ${ }^{3}$. As her life was explored it gradually became clear that she maintained a blandness and passivity in her dealings with people which others would have found difficult to sustain. The patient's conviction that she never felt irritation or anger was questioned. "Did you really feel no anger when he said that, or were you unable to become aware of your resentment because it would have been painful for you to do so?" As interviews progressed, her smoldering, suppressed feelings were exposed and the question arose as to whether it was healthy to leave such feelings unexpressed, even if such expression involved no more than becoming aware of them and putting them clearly into words to herself. "Would it be healthier to become comfortable with such emotions and sometimes to give them expression in acceptable ways?" Events and relationships both at home and in broader interpersonal circles were discussed in this regard.

We examined what she felt would happen if she were to become appropriately firm with others, and even a little angry at times. Did she fear that people would reject her and that she would in time become socially isolated? We suggested that she had "an adventure in assertiveness" ${ }^{\text {"2 }}$ before her and that it was a path to healthier living and recovery from her obsessive disorder. Often this "adventure in assertiveness"began with being firm with shop clerks who tried to push her into buying things that were not quite right for her - clothing that did not exactly fit, or household items which were not precisely what she was looking for, or half sprouted patotoes and wilted cabbages and cauliflowers. As she did these things she discovered that shop clerks and other vendors treated her with more respect and did not try to bully her into sales by scowls, impatient gestures and heckling words. Having made progress in small areas, the patient went on to do the same thing in the more important relationships in her life - with neighbors, with people in social groups, with members of her extended family, and, finally, with her children and her husband. In all these areas she gradually discovered that reasonable assertiveness and firmness brought her more respect and increased affection.

In all these women the formation of their unhealthy patterns of behavior and feeling could be traced to long-term childhood and early adolescent experiences with important people in their lives ${ }^{1}$. They were reared in homes in which any expression of angry or assertive feelings brought a deluge of reproaches and criticism. "Nobody likes angry little girls. If you go on like that nobody will ever like you." "Wipe that scowl off your face. It makes you look ugly." Even mild pouting and silent resistance wee unacceptable. In these and many other ways they were made to feel guilty and depraved if they were in any way assertive, and were molded into passive individuals who were unable even to be aware of hostile feelings and to put them into words to themselves. Parental affection was bought at the price of compliance and passivity; to be angry was to be unloved and rejected. To be the object of criticism or anger became a painful experience for them; to be in the presence of angry or extremely assertive persons, even when they were not the objects of the aggressiveness or in any direct way 
involved, was upsetting to them. In some cases both the parents treated the patient in these unhealthy ways, while in others the father merely reinforced the mother's censures and remained on the dim periphery of the girl's emotional life, leaving the handling of such "problems" to the mother.

Beneath their passive, smilling exteriors these patients had large amounts of repressed anger. They grew from submissive children into compliant adolescents and uncomplaining adults. As might be expected, as adults they had marked problems in disciplining their children, both girls and boys. They childed, pleaded and bickered with them ineffectively; they were unable to be firm and to back up such firmness with clear-cut discipline. They felt in vague, inarticulate ways that any expression of firmness or anger with their children would lead to a "breaking of the dam" and that they would then be swept on to unacceptable extremes. In their coupled obsessions of infanticide and psychosis these long accumulating problems acquired the final symptomatic expression which brought them to our attention.

In later phases of treatment the roots of the patient's discomfort with assertiveness and her resultant passiveness were traced to the experiences of her childhood and early adolescence, which are outlined above $\mathrm{e}^{\mathbf{5}}$. It also became clear in most cases that the persons in her extended family and others who were frequently in the home, or who dealt with her outside it and who might have modified these tendencies, did little to give her a healthier view of herself and outlets for her suppressed emotions. As a result large amounts of simmering anger slowly accumulated beneath her placid exterior and provided the fuel which finally produced her obsessive fears of explosive violence and concomitant insanity.

We have little information about the nine patients who did not have psychotherapy. We saw at intervals of five, six and eight months, in single follow-up consultations which they spontaneously sought, three of them. All three were substantially better and stated that the reassurances and explanations we had given them about their difficulties in their prior consultations with us had been helpful; however, they were still afflicted in varying degrees by their obsessive preoccupations. We have no information about the other six untreated patients but, based on the three women whom we did see, we are hopeful that they had similar ameliorations.

\section{RESULTS AND DISCUSSION}

The seven patients who had psychotherapy improved much in it. Their symptoms slowly receded. By developing the ability to express assertive feelings in ways that were acceptable in their familial and social settings, or at least to become articulately aware of them to themselves, they gradually resolved the causes of their neuroses; of equal importance, they also acquired insight into how they had developed their personality problems. In the therapeutic process they acquired new personality capacities which would contribute to healthier living in the years ahead.

The prognosis of this clinical syndrome thus seems to be good when the patient has psychotherapy ${ }^{7}$. We have scant information about the courses of these patients when they are not treated, but what limited data we have suggests that massive reassurances and careful explanations about the nature of their difficulty helps some of these patients.

\section{REFERENCES}

1. Chapman AH, Chapman-Santanta M. Is it possible to have an unconscious thought? Lancet 1994; 344:1752-1753.

2. Chapman AH, Chapman-Santana M. Handbook of problem-oriented psychoterapy. Northvale NJ: Jason Aronson Publ, in press, Chap 6.

3. Horowitz IM, Rosenberg SE, Bartholomew K. Interpersonal problems, attachment styles and outcome in brief dynamic psychoterapy. J Consult Clin Psychol 1993; 60:549-560.

4. James IA, Blackburn IM. Psychoterapy with obsessive compulsive disorder. Br J Psychiatry 1995; 166:444-450.

5. Novey S. The second look. Baltimore: Johns Hopkins Press, 1968: 81-83,88.

6. Reich JH, Green AI. Effect of personality on outcome of treatment. J Nerv Ment Dis 1990; 178:592-600.

7. Sullivan HS. Obsessionalism in clinical studies in psychiatry. New York: WW Norton, 1956: 229-283. 